\title{
3
}

\section{Robust Cell Line Development Using Meganucleases}

\author{
Jean-Pierre Cabaniols and Frédéric Pâques
}

\section{Summary}

Cell line development for protein production or for the screening of drug targets requires the reproducible and stable expression of transgenes. Such cell lines can be engineered with meganucleases, sequence-specific endonucleases that recognize large DNA target sites. These proteins are powerful tools for genome engineering because they can increase homologous gene targeting by several orders of magnitude in the vicinity of their cleavage site. Here, we describe in details the use of meganucleases for gene targeting in Chinese hamster ovary-K1 cells, with a special emphasis on a gene insertion procedure using a promoter-less marker gene for selection. We have also monitored the expression of genes inserted by meganucleases-induced recombination, and show that expression is reproducible among different targeted clones, and stable over a 4 mo period. These experiments were conducted with the natural yeast I-SceI meganuclease, but the general design and process can also be applied to engineered meganucleases.

Key Words: Cell line development; double-strand break; gene targeting; homologous recombination; I-SceI; meganucleases; protein production.

\section{Introduction}

Homologous recombination is a powerful tool for genome engineering. Since the first gene targeting experiments in yeast more than $25 \mathrm{yr}$ ago $(1,2)$, homologous recombination (HR) has been used to insert, replace, or delete genomic sequences in a variety of cells (3-5). However, targeted events occur at a very low frequency in mammalian cells. The frequency of HR can be significantly increased by a specific DNA double-strand break (DSB) in the targeted locus $(6,7)$. Such DSBs can be delivered with meganucleases, sequence-specific endonucleases that recognize large DNA target sites ( $>12 \mathrm{bp}$ ). Because of their exquisite specificity, these proteins can cleave a unique chromosomal sequence without affecting global genome integrity. Natural meganucleases are essentially represented by homing endonucleases, a widespread class of proteins found in eukaryotes, bacteria, and archae (8). Early studies of the I-SceI and homothalic switching endonuclease 
have illustrated how the cleavage activity of these proteins initiates HR events in living cells and demonstrated the recombinogenic properties of chromosomal DNA DSBs $(\mathbf{9}, \mathbf{1 0})$. Since then, meganucleases-induced recombination has been successfully used for genome engineering purposes in bacteria (11), mammalian cells $(6,7,12-14)$, mice (15), and plants $(16,17)$.

However, the use of meganucleases-induced recombination has long been limited by the repertoire of natural meganucleases; although several hundreds of other meganucleases had been identified in between $(8)$, the diversity of cleavable sequences was too limited to address the complexity of genomes. In fact, only artificial loci, wherein an I-SceI cleavage site had been introduced, could be engineered. Recently, the making of artificial meganucleases, based on homing endonucleases $(\mathbf{1 8 , 1 9})$ or zinc-finger proteins $(\mathbf{2 0 , 2 1 )}$, has considerably enlarged the number of sequences that can be targeted. The production of such new proteins opens the door for the engineering of natural chromosomal sequences.

Here we present a general overview on how to use meganucleases to induce gene correction, gene insertion, or gene replacement. We provide precise protocols for the creation and characterization of gene targeting events, and give a brief survey of the impact of insertion or deletion size on the efficiency of the process, with a special emphasis on gene insertion. Gene insertion can be used, for example, to insert genes of interest in specific loci, for heterologous protein production. Recombinant therapeutic proteins are today mostly produced in mammalian cells such as Chinese hamster ovary (CHO), mouse SP2/0 and NS0 cells, or the human PerC.6 cell line, stably transfected with the gene of interest (22). In the process of selecting highly expressing clones, the level and stability of protein expression are two major criteria. Furthermore, obtaining reproducible results from one clone to another would be an advantage in terms of screening efforts. These principles also apply to the generation of cells for screening of specific drug targets such as $\mathrm{G}$ protein-coupled receptors. In order, to illustrate the various advantages of meganucleases-induced gene targeting for this specific kind of application, we provide protocols to monitor the expression of inserted genes and data of expression stability following gene targeting.

In all the experiments described in Subheading 3., we use the I-SceI meganuclease, which remains today the "gold standard" for DSB-induced recombination, in terms of efficacy and specificity. However, the same protocols can be used to induce similar levels of gene correction or insertion with engineered meganucleases derived from the I-CreI homing endonuclease, which were described in recent reports $(\mathbf{1 8 , 1 9 )}$.

\section{Materials}

\subsection{Cell Culture and Transfection}

1. Phosphate-buffered saline (PBS) (Invitrogen-Life Science, Carlsbad, CA).

2. Kaighn's modified F-12 medium (F12-K) (Invitrogen-Life Science) is supplemented with $2 \mathrm{~m} M \mathrm{~L}$-glutamine, penicillin $(100 \mathrm{UI} / \mathrm{mL})$, streptomycin $(100 \mu \mathrm{g} / \mathrm{mL})$, amphotericin B 
(Fongizone) $(0.25 \mu \mathrm{g} / \mathrm{mL})$ (Invitrogen-Life Science), and $10 \%$ fetal bovine serum (Sigma-Aldrich Chimie, St. Louis, MO).

3. Freezing medium: complete F12-K medium supplemented with $10 \%$ Dimethylsulfoxyde.

4. Puromycin dihydrochloride (Sigma-Aldrich Chimie). For CHO-K1, the concentration of $10 \mu \mathrm{g} / \mathrm{mL}$ is used.

5. Hygromycin B solution (Sigma-Aldrich Chimie). For CHO-K1, the concentration of $0.6 \mathrm{mg} / \mathrm{mL}$ is used.

6. Trypsin-EDTA solution (Invitrogen-Life Science).

7. Versene solution (Invitrogen-Life Science).

\subsection{Molecular Characterization of Targeted Events by Southern Blot Using Nonradioactive Probes}

\subsubsection{Genomic DNA (gDNA) Preparation and Digestion}

1. gDNA lysis buffer: $0.5 \%$ sodium dodecyl sulfate (SDS), $40 \mathrm{~m} M$ Tris-HCl, $40 \mathrm{~m} M$ EDTA, $200 \mathrm{~m} M \mathrm{NaCl}$, pH 7.5. Store at $4^{\circ} \mathrm{C}$.

2. Proteinase $\mathrm{K}(20 \mathrm{mg} / \mathrm{mL})$ (Eurobio, Les Ulis, France).

3. TE buffer: $10 \mathrm{~m} M$ Tris-HCl, $1 \mathrm{~m} M$ EDTA, $\mathrm{pH}$ 8.0.

\subsubsection{DNA Electrophoresis and Transfer}

1. Running buffer: $0.5 \mathrm{X}$ Tris-acetate EDTA: $20 \mathrm{~m} M$ Tris-acetate, $1 \mathrm{~m} M$ EDTA pH 8.0. Prepare a 50X stock solution.

2. Denaturation buffer: $0.5 \mathrm{M} \mathrm{NaOH}, 1.5 \mathrm{M} \mathrm{NaCl}$. Store at room temperature.

3. Neutralization buffer: $0.5 M$ Tris- $\mathrm{HCl}(\mathrm{pH} 7.4), 1.5 \mathrm{M} \mathrm{NaCl}$. Store at room temperature.

4. Transfer buffer: $10 X \mathrm{SSC}(1.5 \mathrm{M} \mathrm{NaCl}, 0.15 M \mathrm{Na}$-citrate). Make 20X stock solution. Store at room temperature.

5. Hybond N+ membrane (Amersham, Little Chalfont, England).

6. 3 MM Chr Whatmann paper (Schleicher and Schuell, Maldstone, England).

\subsubsection{Probe Labeling}

1. Digoxygenin (DIG) DNA-labeling kit (Roche Diagnostics, Mannheim, Germany).

2. Nucleospin column (Macherey-Nagel, Düren, Germany).

\subsubsection{Hybridization}

1. Hybridization buffer: $0.5 M$ phosphate buffer pH 7.2, 7\% SDS, $1 \mathrm{~m} M$ EDTA. Store at room temperature.

\subsubsection{Wash and Anti-DIG Probing}

1. Wash buffer: $40 \mathrm{~m} M$ phosphate buffer $\mathrm{pH} 7.2,1 \%$ SDS. Store at room temperature.

2. Buffer I: $0.1 M$ maleic acid, $0.15 M \mathrm{NaCl}, \mathrm{pH}$ 7.5. Prepare a $10 \mathrm{X}$ stock solution. Adjust $\mathrm{pH}$ with $\mathrm{NaOH}$. Store at room temperature. Add $0.3 \%$ Tween-20 before use.

3. Buffer II: buffer I supplemented with $10 \%$ (v/v) blocking reagent.

4. Buffer III: $100 \mathrm{~m} M$ Tris- $\mathrm{HCl} \mathrm{pH} 9.5,100 \mathrm{mM} \mathrm{NaCl}, 50 \mathrm{~m} M \mathrm{MgCl}_{2}$. Store at room temperature. 
5. Alkaline phosphatase-conjugated anti-DIG Fab (Roche Diagnostics, Mannheim, Germany). Store at $4^{\circ} \mathrm{C}$.

6. Blocking reagent 10X (Roche Diagnostics, Mannheim, Germany). Store at $4^{\circ} \mathrm{C}$.

7. CDP star-chemiluminescence substrate for alkaline phosphatase-(Roche Diagnostics, Mannheim, Germany). Store at $4^{\circ} \mathrm{C}$.

\subsection{Protein Production}

\subsubsection{Measure of $\beta$-Galactosidase Activity}

1. Lysis buffer: $10 \mathrm{~m} M$ Tris-HCl $\mathrm{pH} 7.5,150 \mathrm{~m} M \mathrm{NaCl}, 0.1 \%$ Triton X-100. Store at $4^{\circ} \mathrm{C}$

2. $100 \mathrm{X} \mathrm{Mg}$ buffer: $100 \mathrm{mM} \mathrm{MgCl}, 35 \% \beta$-mercaptoethanol. Store at room temperature.

3. Orthonitrophenyl- $\beta$-D-galactopyranoside (ONPG): prepare a $8 \mathrm{mg} / \mathrm{mL}$ solution in water. Store at $-20^{\circ} \mathrm{C}$.

4. $0.1 M \mathrm{Na}_{2} \mathrm{HPO}_{4} / \mathrm{NaH}_{2} \mathrm{PO}_{4} \mathrm{pH} 7.5$.

\subsubsection{Antibodies and FACS Reagents}

1. Biotin-conjugated mouse antihuman CD4 monoclonal antibody (Becton Dickinson, San Jose, CA).

2. Biotin-conjugated mouse isotype control monoclonal antibody (Becton Dickinson).

3. Streptavidin-conjugated PhycoErythrin (Streptavidin-PE) (Becton Dickinson).

4. FACS buffer: PBS supplemented with $2 \%$ fetal bovine serum.

\section{Methods}

Meganucleases (and more generally gene targeting) can be used to trigger gene correction as well as gene insertion, deletion, or replacement. Obtaining the desired kind of events does not simply depend on a standard protocol, but also on the design of the targeting vector, also referred to as "repair matrix," because they actually provide a matrix or template for the DSB-repair process initiated by I-SceI and other meganucleases. In this chapter, we will provide a few examples for the design of the repair matrix for gene correction, gene insertion, and gene replacement.

We take, as an example, experiments that were performed on a model cell line with a puromycin-resistance marker as target gene. This gene is under the transcriptional control of the human EF1 $\alpha$ promoter, and about $1 \mathrm{~kb}$ of additional EF1 $\alpha$ sequences, corresponding to the two first untranslated exons and first intron, are present between the promoter and the puromycin-resistance gene. Furthermore, a cleavage site for the natural endonuclease I-SceI was inserted $132 \mathrm{bp}$ downstream of the ATG of puromycin-resistance gene, thus inactivating this gene. The construct has been stably integrated in $\mathrm{CHO}-\mathrm{K} 1$ cell genome in single copy. Then, different repair matrix were constructed, to modify this locus by gene targeting.

The first repair matrix was designed for the correction of the puromycinresistance gene (Fig. 1A). Gene correction should result in the removal of $22 \mathrm{bp}$ including the I-SceI cleavage site, and the consequent restoration of a functional 


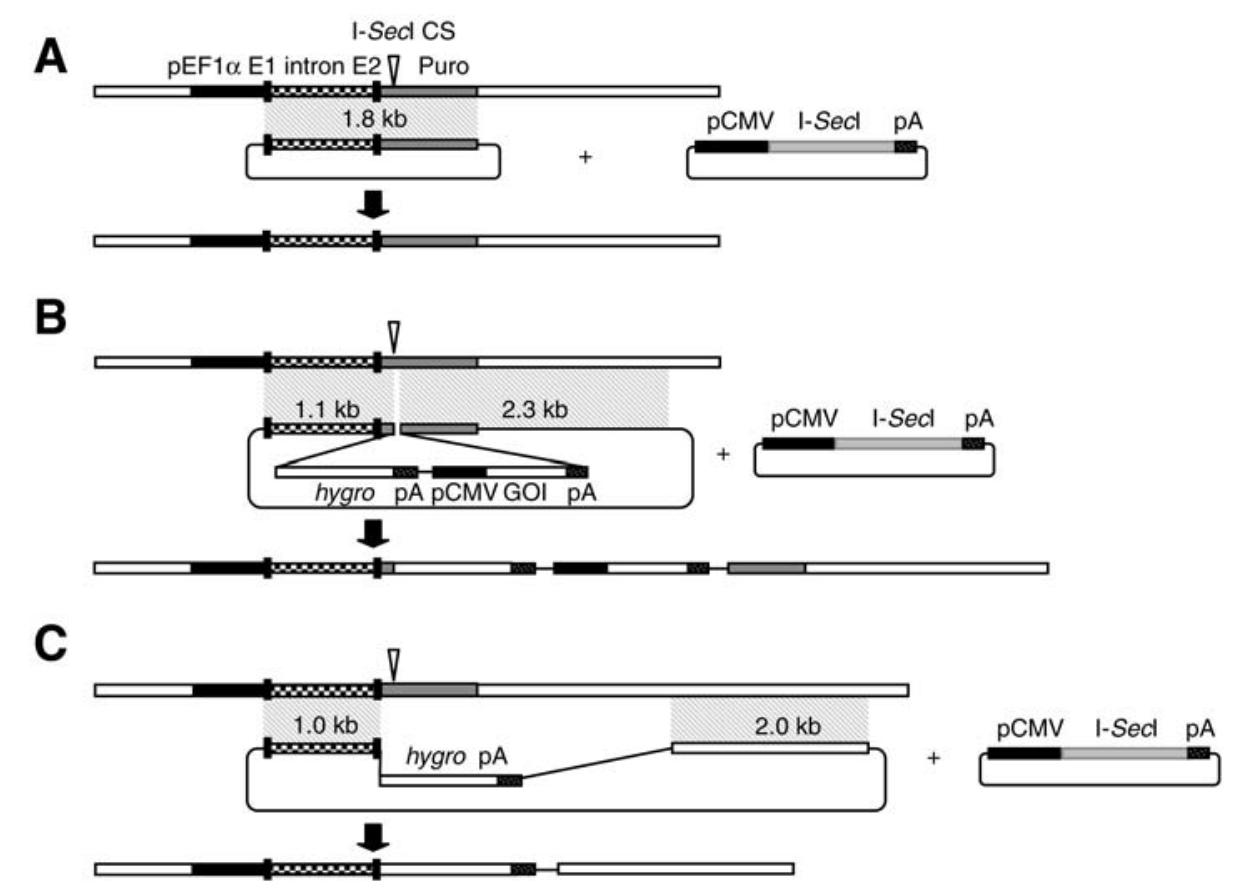

Fig. 1. Design of reporter system and repair matrix for gene correction (A), gene insertion (B), and gene replacement (C). The puromycin-resistance gene is interrupted by an I-SceI cleavage site (CS) and under the control of the EFI $\alpha$ promoter. For gene correction, the repair matrix includes $1.8 \mathrm{~kb}$ of homologous sequence corresponding to the two untranslated exons (E1, E2) and first intron and a full length puromycin gene. For gene insertion, the repair matrix corresponds to a promoter-less hygromycin-resistance gene alone or with a complete expression cassette that is flanked by two stretches of homologous sequences $(1.1 \mathrm{~kb}$ and $2.3 \mathrm{~kb})$. The repair matrix for gene replacement is very similar to the insertion matrix except that (i) the $3^{\prime}$ homology sequence starts after the puromycin polyA signal (ii) all sequences from the puromycin-resistance gene have been removed from the $5^{\prime}$ homologous sequence. Homology lengths are depicted by hatched boxes. GOI stands for gene of interest ( $\beta$-galactosidase or CD4 in this study).

puromycin-resistance cassette. The gene correction matrix includes a noninterrupted puro $^{R}$ gene, with EF1 $\alpha$ sequences in 5' (these sequences include exon 1 and 2 and intron 1 , but not the promoter). It shares a total of $1.8 \mathrm{~kb}$ of homology with the targeted locus, with $1.1 \mathrm{~kb}$ in $5^{\prime}$ of the I-SceI site, and $0.7 \mathrm{~kb}$ in $3^{\prime}$.

Second, a series of three insertion vectors were designed by cloning inserts of various sizes in the puromycin-resistance gene (Fig. 1B). These repair matrix are intended to insert novel sequences within the targeted locus. The heterologous inserts are surrounded by $1.1 \mathrm{~kb}$ of homologous sequences in $5^{\prime}$ (the EF1 $\alpha$ exons and intron), and $2.3 \mathrm{~kb}$ in $3^{\prime}$ (longer than in the gene correction vector). The simplest 
insertion vector includes a promoter-less hygromycin-resistance cassette of $1.3 \mathrm{~kb}$, whereas the two others contain an additional expression cassette, coding for the Escherichia coli $\beta$-galactosidase enzyme or the human CD4 transmembrane protein, and resulting in total inserts length of 5.5 and $4.4 \mathrm{~kb}$, respectively. Note that in these insertion vectors, the hygromycin-resistance gene is modified by addition in its $5^{\prime}$ end of the first $132 \mathrm{bp}$ (44 first amino acids) of the puromycinresistance gene (132 bp upstream of the I-SceI site), resulting in the production of a fusion protein that confers resistance to hygromycin $\mathrm{B}$.

Third, one can envision, in several applications, the total replacement of the puromycin-resistance gene by another selection marker. To meet this purpose, a gene replacement vector was produced by modifying the $3^{\prime}$ homologous sequence of the first gene insertion vector (Fig. 1C). In this construct, the $3^{\prime}$ homologous sequence (about $2 \mathrm{~kb}$ in length) started $2 \mathrm{~kb}$ after the end of the puromycin-resistance ORF, and all sequences from the puromycin-resistance gene (132 bp) have been removed from the $5^{\prime}$ homologous sequence (for a total deletion of $3 \mathrm{~kb}$ ). The $5^{\prime}$ homologous sequence is also modified by removing all sequences from the puromycin-resistance gene.

In the experiments described in Subheading 3., the repair matrix and the I-SceI expression vector (Fig. 1) are cotransfected in our model cell line. For maximal efficiency, we use a vector wherein I-SceI is placed under the control of the cytomeganlovirus promoter and described in a former report (7). On targeted insertion, the functional puromycin- or hygromycin-resistance gene is placed downstream of the EF1 $\alpha$ sequences, and transcribed from the EF1 $\alpha$ promoter. In contrast, random insertion will not create an expressed puromycin or hygromycinresistance cassette unless the cassette is fortuitously inserted just downstream of a functional promoter. As such "promoter trap" events are supposed to be very rare, our system allows for a considerable enrichment for targeted events among transformed puro $^{\mathrm{R}}$ or hygro ${ }^{\mathrm{R}}$ cell lines. This kind of "refinement" is not compulsory, but can greatly simplify the task of the researcher.

\subsection{Cell Transfection and Selection}

1. All the transfection experiments were done with the Amaxa Electroporation system (Amaxa GmbH, Koeln, Germany), which ensures more than 50\% transfection efficiency.

2. The adherent cells are washed once with PBS, then incubated with trypsin-EDTA solution for $5^{\prime}$ at $37^{\circ} \mathrm{C}$ and collected in a $15-\mathrm{mL}$ conical tube (Note 1). After centrifugation at $300 \mathrm{~g}$ for $5 \mathrm{~min}$, the supernatant is discarded and the cell pellet is resuspended in $10 \mathrm{~mL}$ of complete F12K medium. Cells are numerated, centrifuged again, and adjusted at the concentration of $2 \times 10^{7} \mathrm{cells} / \mathrm{mL}$ in Amaxa solution T.

3. $2-15 \mu \mathrm{g}$ of plasmid DNA (Note 2$)$ is added to $100 \mu \mathrm{L}$ of cells $\left(2 \times 10^{6}\right.$ cells) in an Amaxa electroporation cuvet. The cells and DNA are gently mixed before insertion in the electroporation chamber of the Amaxa electroporation apparatus (Note 3). For CHO-K1 cells, the manufacturer recommends the use of program U-23. 
4. After electroporation, $0.5 \mathrm{~mL}$ of prewarmed complete $\mathrm{F} 12 \mathrm{~K}$ medium is added to the cuvet and cells are gently transferred into a $10-\mathrm{cm}$ culture dish containing $10 \mathrm{~mL}$ of prewarmed complete F12K medium. Dishes are incubated in a $37^{\circ} \mathrm{C}, 5 \% \mathrm{CO}_{2}$ humidified incubator for $24 \mathrm{~h}$.

5. After a $24 \mathrm{~h}$ recovery period, transfected cells are washed once with PBS, then incubated with trypsin-EDTA solution for $5^{\prime}$ at $37^{\circ} \mathrm{C}$ and collected in a $15-\mathrm{mL}$ conical tube. Cells are counted and cloned in 96-well plates at the density of 500 cells/well in complete F12K medium supplemented with the selecting reagent. Examples of selecting reagent: puromycin solution is added at the final concentration of $10 \mu \mathrm{g} / \mathrm{mL}$. Hygromycin B solution is added at the final concentration of $0.6 \mathrm{mg} / \mathrm{mL}$.

6. About $10 \mathrm{~d}$ later, puromycin $\left(\right.$ puro $^{\mathrm{R}}$ )- or hygromycin $\left(\right.$ hygro $^{\mathrm{R}}$ )-resistant clones can be counted. Positive clones are amplified by sequential passage onto 12 -well plates, 6 -well plates, and finally $10-\mathrm{cm}$ dishes. The selecting agent is maintained through all these steps. At this point, clones are cryo-conserved in freezing medium.

The frequencies of puro $^{R}$ and hygro ${ }^{R}$ cells are summarized in Table 1. These frequencies are established by dividing the number of wells containing puro $^{\mathrm{R}}$ and hygro $^{\mathrm{R}}$ cells by the total number of plated cells (For puro ${ }^{\mathrm{R}}$ cells, this number is an underestimation: if puro $^{\mathrm{R}}$ cells occur at a frequency of $3 \times 10^{-3}$, and if 500 cells were plated per well, there might be two puro $^{\mathrm{R}}$ clones in several). However, such phenotypes can result either from gene targeting, or from random integration of the repair matrix downstream of an active promoter. Indeed, hygro ${ }^{\mathrm{R}}$-resistant clones (but for unknown reasons, no puro $^{\mathrm{R}}$ clone) were also obtained when the repair matrix were transfected without the I-SceI expressing vector (Table 1). Therefore, the frequencies of targeted events can only be obtained after molecular characterization.

\subsection{Molecular Characterization of Targeted Events by Southern Blot Using Nonradioactive Probes}

To identify targeted events, the gDNA of hygro ${ }^{\mathrm{R}}$ and puro $^{\mathrm{R}}$ clones can be analyzed by Southern blotting, using restriction enzymes that will discriminate targeted loci from nonrecombined ones. An example is shown on Fig. 2.

\subsection{1. gDNA Preparation and Digestion}

1. Confluent cells from $10-\mathrm{cm}$ dish are collected in a $15-\mathrm{mL}$ conical tube. Cells are washed once with PBS. After centrifugation $(300 g)$ supernatants are discarded and cell pellets are thoroughly vortexed.

2. $500 \mu \mathrm{L}$ of gDNA lysis buffer is added to cell pellets and incubated at room temperature for $30 \mathrm{~min}$. $15 \mu \mathrm{L}$ of proteinase $\mathrm{K}$ solution $(20 \mathrm{mg} / \mathrm{mL})$ is added to the lysates. Incubate at $56^{\circ} \mathrm{C}$ overnight.

3. The next day, $10 \mathrm{~mL}$ of ethanol $85 \%$ is added. Mix gently then incubate for $10 \mathrm{~min}$ at room temperature. The gDNA pellet will sediment at the bottom of the tube.

4. DNA pellet is transferred in a $1.5-\mathrm{mL}$ microfuge tube and centrifuged at $16,000 \mathrm{~g}$ for $30 \mathrm{~min}$ at $4{ }^{\circ} \mathrm{C}$. Supernatants are discarded. DNA pellets are rinsed with $0.5 \mathrm{~mL}$ ethanol $70 \%$, centrifuged again for $10 \mathrm{~min}$ at $16,000 \mathrm{~g}$. A maximum of ethanol is 


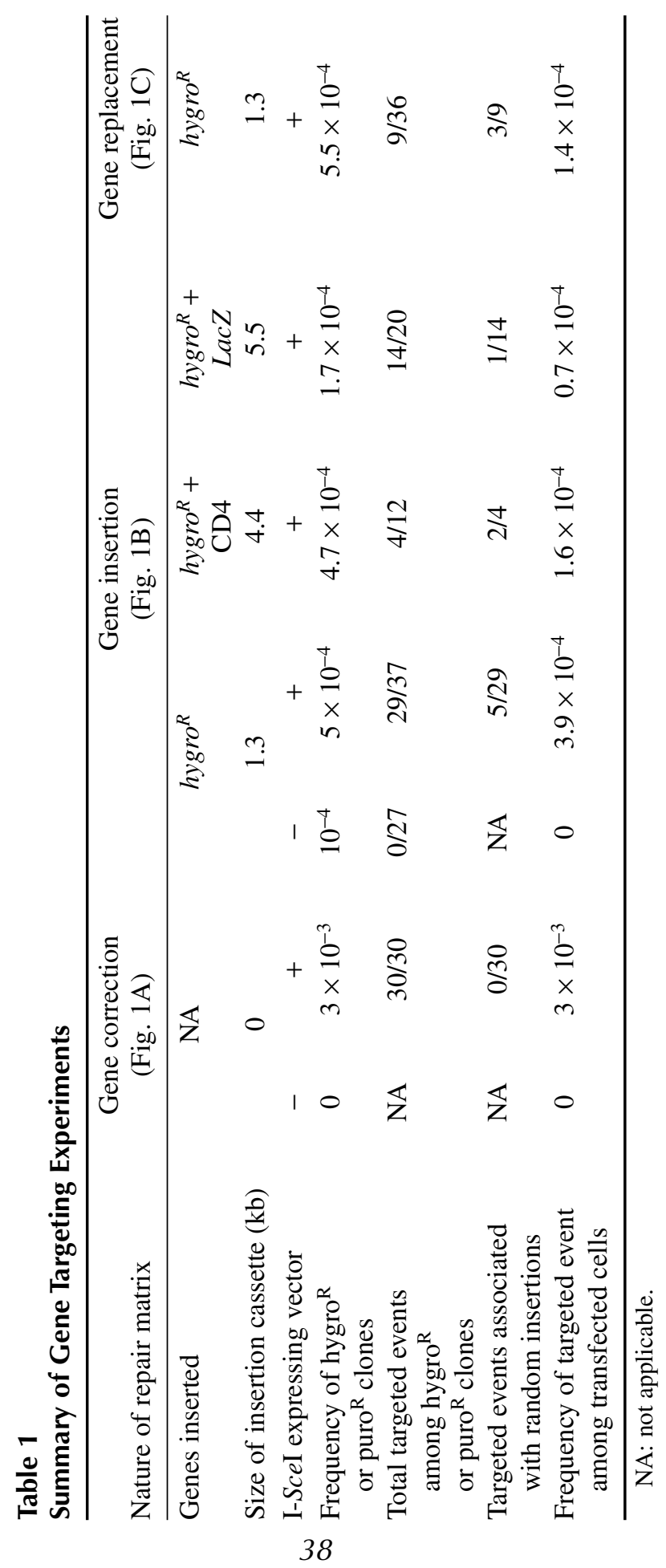




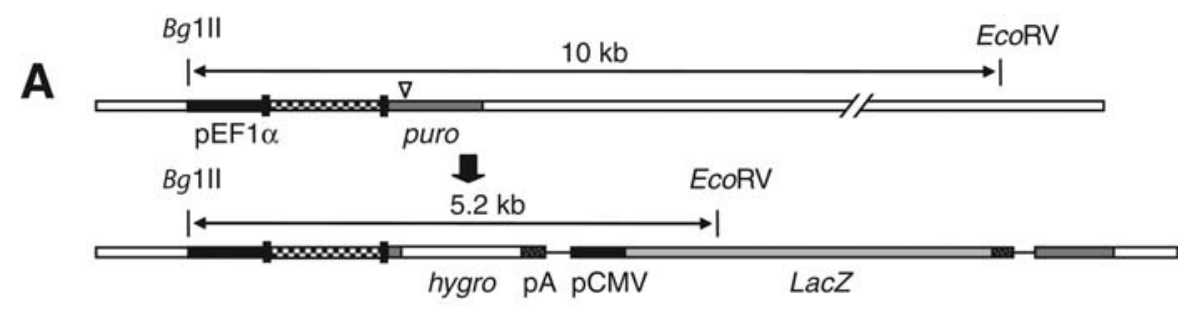

B

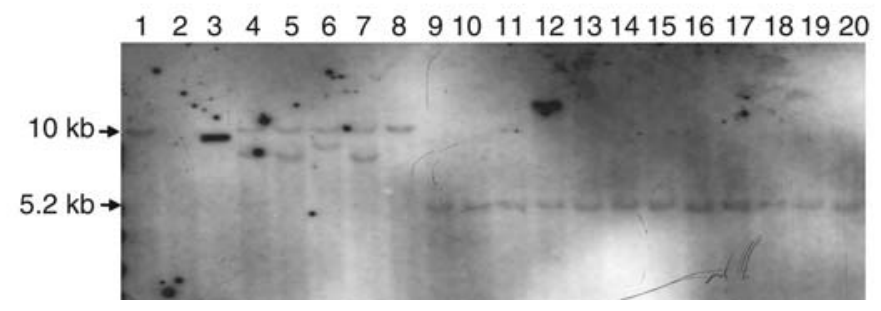

Fig. 2. Southern blot analysis of hygro ${ }^{\mathrm{R}}$ clones using nonradioactive probes. Here, we present the analysis of clones obtained with the repair matrix containing the hygro ${ }^{R}-$ LacZ $5.5 \mathrm{~kb}$ insert. (A) Principle of analysis. gDNA is digested with restriction enzymes $B g l \mathrm{II}$ and EcoRV. After electrophoresis and DNA transfer, the blot is hybridized with a probe corresponding to the first intron. In the parental clone, a $10 \mathrm{~kb}$ band corresponding to the nontargeted puro $^{\mathrm{R}}$ locus should be detected. On targeted insertion of the hygro ${ }^{R}:$ LacZ cassette, the $10 \mathrm{~kb}$ band disappears and should be replaced by a $5.2 \mathrm{~kb}$ band. In nontargeted clones, additional bands of various sizes correspond to random insertion of the repair matrix. (B) Southern blotting. Lane 1; control parental cell line, lane 2; CHO-K1 cell line before transformation with reporter cassette, lane $\mathbf{3}$; linearized repair matrix plasmid, lanes 4-20; hygro $^{R}$ clones selected after transfection. Random insertion is observed in lanes 4-7. Lane 8 likely corresponds to integration of the hygro ${ }^{R}$ ORF without the intron. Targeted insertion is observed in lanes 9-11 and 13-20. Targeted insertion can also be associated with random insertion, revealed by an additional band (lane 12).

removed. DNA pellets are dried for $5 \mathrm{~min}$ at $37^{\circ} \mathrm{C}$ (Note 4) before the addition of $100-200 \mu \mathrm{L}$ of TE buffer. Resuspended DNA is incubated at $65^{\circ} \mathrm{C}$ until complete dissolution (Note 5). DNA concentration is measured at $260 \mathrm{~nm}$ with a spectrophotometer.

5. Usually, $10 \mu \mathrm{g}$ of gDNA is digested overnight with a two- to fivefold excess of enzymes.

\subsubsection{DNA Electrophoresis and Transfer}

1. Digested gDNA are loaded on a $0.8 \%$ agarose gel in $0.5 \mathrm{X}$ Tris-acetate EDTA buffer and run at $5 \mathrm{~V} / \mathrm{cm}$ for $1 \mathrm{~h}$ then $8.3 \mathrm{~V} / \mathrm{cm}$ for $4-5 \mathrm{~h}$ for a total migration length of $12-14 \mathrm{~cm}$ (Note 6). Take a photograph.

2. The gel is soaked first in denaturation buffer for $30 \mathrm{~min}$ at room temperature under gentle agitation, then in neutralization buffer for $30 \mathrm{~min}$ and again in new neutralization buffer for $15^{\circ} \mathrm{C}$. Finally, the gel is soaked in $10 \mathrm{X} \mathrm{SSC}$ for $5^{\circ} \mathrm{C}$. 
3. The separated DNA is blotted onto Hybond N+ nylon membrane by capillarity in 10X SSC overnight. Briefly, the gel is positioned on a piece of Whatmann $3 \mathrm{MM}$ paper that has been previously soaked in transfer buffer. The extremities of the paper are lying in a tank containing the transfer buffer. The piece of nylon membrane (previously soaked in $\mathrm{ddH}_{2} \mathrm{O}$ ) is placed on the top of the gel and air bubbles are removed by rolling a clean plastic pipet. Three sheets of Whatmann $3 \mathrm{MM}$ paper are placed onto the membrane. The upward flow of buffer will be ensured by a stack of paper towels positioned on the top. Finally, a glass plate with a weight is applied to maintain a tight connection between the layers.

4. The next morning, the membrane is removed from the transfer system and incubated a few minutes in $40 \mathrm{mM} \mathrm{Na} \mathrm{NPO}_{2}$. The membrane is then dried on a piece of Whatmann $3 \mathrm{MM}$ paper and DNA is cross-linked to the membrane using a Ultraviolet Stratalinker (Stratagene) (Note 7).

\subsubsection{Probe Labeling}

1. $1 \mu \mathrm{g}$ of DNA probe (between $500 \mathrm{bp}$ and $1 \mathrm{~Kb}$ long) is denatured for $10 \mathrm{~min}$ at $100^{\circ} \mathrm{C}$ in a water bath.

2. The denatured DNA is labeled with Klenow enzyme (12 IU) in the presence of random hexamer oligonucleotides, deoxynucleotides, and DIG-conjugated dUTP at $37^{\circ} \mathrm{C}$ overnight in a final reaction volume of $100 \mu \mathrm{L}$.

3. The next day, the probe is purified on a Nucleospin column (Macherey-Nagel, Düren, Germany) and aliquoted. The probe aliquots are stored at $-20^{\circ} \mathrm{C}$ until use.

\subsubsection{Hybridization}

1. The membrane is soaked in $\mathrm{ddH}_{2} \mathrm{O}$ for 5 min then placed into a hybridization bottle with $20 \mathrm{~mL}$ of hybridization buffer. The bottle is incubated for $1 \mathrm{~h}$ in a hybridization oven at $68^{\circ} \mathrm{C}$.

2. The DIG-labeled probe (use about $15 \mathrm{ng} / \mathrm{mL}$ hybridization buffer) is denatured for $10^{\circ} \mathrm{C}$ in a water bath at $100^{\circ} \mathrm{C}$, then is added to $20 \mathrm{~mL}$ of hybridization buffer. The hybridization is performed at $68^{\circ} \mathrm{C}$ overnight.

\subsubsection{Wash and Anti-DIG Probing}

1. The probe is recovered and stored at $-20^{\circ} \mathrm{C}$ (Note 8). The blot is washed two times in washing buffer (equilibrated at $68^{\circ} \mathrm{C}$ ) at $68^{\circ} \mathrm{C}$ for 5 min then once in $100 \mathrm{~mL}$ of buffer I at room temperature under agitation on a retro orbital shaker (Certomat ${ }^{\circledR} \mathrm{RM}$,

B. Braun Biotech International $\mathrm{GmbH}$, Melsungen, Germany) (30 rpm).

2. The membrane is wrapped in a plastic bag and $20 \mathrm{~mL}$ of buffer II is added. This step corresponds to the blocking step. The membrane is shaken for $30 \mathrm{~min}$ at $250 \mathrm{rpm}$. Remove the buffer and add $20 \mathrm{~mL}$ of buffer II with $0,0375 \mathrm{U} / \mathrm{mL}$ of anti-DIG antibody. Incubate membrane for another $30 \mathrm{~min}(250 \mathrm{rpm})$.

3. The membrane is removed from the plastic bag and placed immediately in buffer I. The membrane is washed two times for 30 min under gentle agitation (30 rpm).

4. Finally, the membrane is incubated for $3 \mathrm{~min}$ in buffer III (Note 9).

5. The membrane is placed on a plastic sheet. $3 \mathrm{~mL}$ of buffer III plus $10 \mu \mathrm{L}$ of CDP star is carefully layered over the membrane and a second sheet of plastic is placed on top of it. After 5 min of incubation, excess of liquid is wiped out and the plastic sheets are sealed. 
6. The membrane is exposed in a cassette to an X-ray film at room temperature. Time of exposure will depend on the probe efficiency. Usually $4 \mathrm{~h}$ exposure is enough but can be longer (overnight for example) (Note 10).

Results are summarized in Table 1. For gene correction, the frequency of puro ${ }^{R}$ clones reflects the frequency of targeted events, as only corrected puromycin gene can be selected. With the other cassettes, the frequency of gene targeting seems to decrease when the size of the insert increases. As shown on Fig. 2 (Lane 12), targeted insertion can be associated with random insertion in the same clone, but these double events remain a minority, except with the $4.4 \mathrm{~kb}$ cassette (two out of four targeted clones). In addition, the replacement of the whole puro $^{R}$ gene with additional $3^{\prime}$ sequences $(3 \mathrm{~kb})$ seems to be more demanding than the simple insertion of the hygro ${ }^{R}$ cassette. However, there is only a two-fold decrease in efficiency. Altogether, these results argue that large insertions $(5.5 \mathrm{~kb})$ and deletions $(3 \mathrm{~kb})$ can be obtained by meganucleases-induced gene targeting. Note that when the repair matrix were transfected without the I-SceI expressing plasmid, we never could obtain any targeted clone (see Table 1).

\subsection{Protein Production}

Insertion of different heterologous sequences at the same locus can be interesting for protein production or drug screening purpose. The level of protein expression and its stability are both major criteria during cellular clone selection. Furthermore, reproducibility of expression would decrease the screening effort and allow for better planification. An insertion in the same locus would ensure reproducible levels of expression independently of the inserted sequences. As an example, we monitor the expression level of two different proteins ( $\beta$-galactosidase and human CD4) over a 4 mo period after I-SceI-induced gene insertion. In these experiments, only clones with targeted insertions and without additional random inserts were considered.

\subsubsection{Measure of $\beta$-Galactosidase Activity}

1. Cells are washed twice in PBS then incubated with $5 \mathrm{~mL}$ of trypsin-EDTA solution. After $5 \mathrm{~min}$ incubation at $37^{\circ} \mathrm{C}$, cells are collected in a $15-\mathrm{mL}$ conical tube and counted.

2. $2 \times 10^{6}$ cells are incubated with $200 \mu \mathrm{L}$ of lysis buffer on ice for $30 \mathrm{~min}$.

3. Cell lysates are centrifuged for $2 \mathrm{~min}$ at $10,000 \mathrm{~g}$ at $4^{\circ} \mathrm{C}$. Supernatants are transferred in a clean $1.5-\mathrm{mL}$ microfuge tube.

4. $20 \mu \mathrm{L}$ of 1/10th dilution of cell lysates are mixed with: $2 \mu \mathrm{L}$ of Mg $100 \mathrm{X}$ buffer, $22 \mu \mathrm{L}$ of ONPG $(8 \mathrm{mg} / \mathrm{mL})$ solution and $156 \mu \mathrm{L}$ of $0.1 \mathrm{M} \mathrm{Na}_{2} \mathrm{HPO}_{4} \mathrm{pH} 7.5$ in a $96-$ well plate.

5. Plates are incubated at $37^{\circ} \mathrm{C}$ for $45 \mathrm{~min}$. Optical density is read at $415 \mathrm{~nm}$ using a microplate reader (Model 550, BioRad, Hercules, CA).

The production level of $\beta$-galactosidase has been measured in this way for 4 different targeted clones during 16 wk. The graph shown on Fig. 3A displayed the 


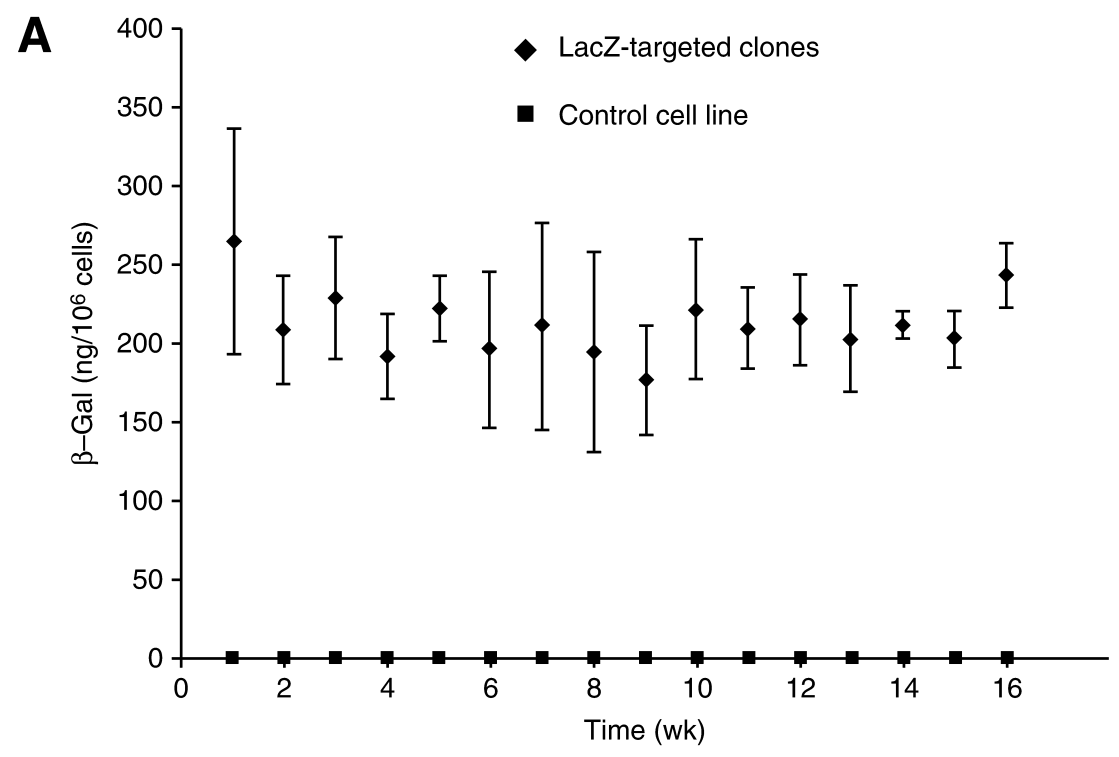

Fig. 3. (Continued)

mean level of expression for these 4 clones as compared with nonproducing cell line, showing a very small dispersion of the measurements.

\subsubsection{FACS Detection of CD4-Expressing Cells}

1. Cells are washed twice in PBS and incubated with $2 \mathrm{~mL}$ of Versene solution (Note 11). After 5 min incubation at $37^{\circ} \mathrm{C}$, cells are collected in a $15-\mathrm{mL}$ conical tube. The cells are counted.

2. $10^{6}$ cells are transferred in 5-mL tube (Falcon, 2058) and centrifuged at $300 \mathrm{~g}$ for 5 min at $4^{\circ} \mathrm{C}$. Cells are washed once with FACS buffer. Cell pellets are resuspended in $20 \mu \mathrm{L}$ of biotin-conjugated anti-CD4 or biotin-conjugated isotype control antibody. After $30 \mathrm{~min}$ of incubation on ice, cells are washed once in FACS buffer. Cell pellets are then incubated with $20 \mu \mathrm{L}$ of streptavidin-conjugated PE for $30 \mathrm{~min}$ on ice and protected from light. The cells are washed once in FACS buffer and finally resuspended in $0.5 \mathrm{~mL}$ of FACS buffer.

3. The cells sample are analyzed on a FACS vantage II (BD Bioscience, San Jose, CA) using a $488 \mathrm{~nm}$ Ion-Argon laser. The emitted fluorescence (emission wavelength at $\sim 580 \mathrm{~nm}$ ) is collected in the fluorescence 2 channel.

The level of CD4 expression of a targeted clone has been analyzed by FACS for two different targeted clones during $16 \mathrm{wk}$. The pattern of CD4 expression for one of these clones is shown on Fig. 3B. For the other one the pattern is very similar (Data not shown). Thus, as for $\beta$-galactosidase, we demonstrated that the level of expression is very similar from clones to clones and that the expression is very stable over a long period of time. 
B
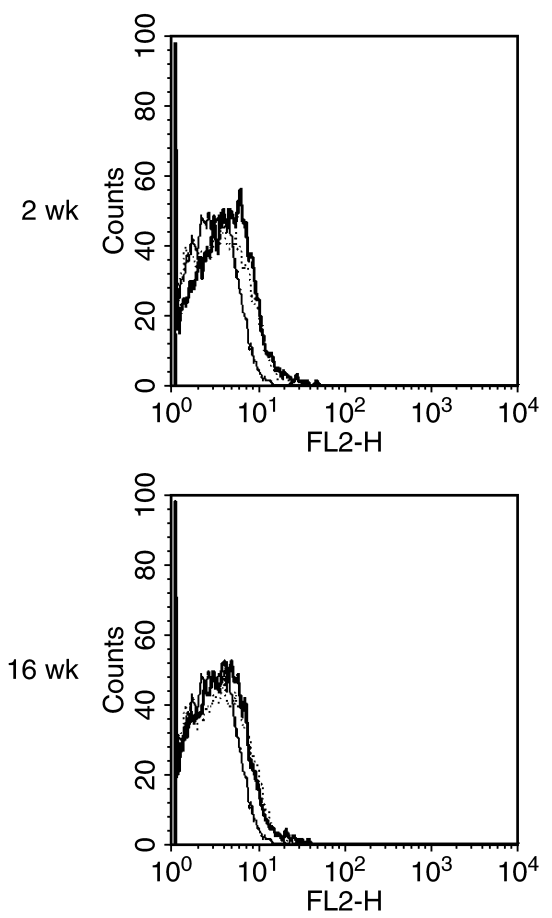

Anti-CD4 Mab
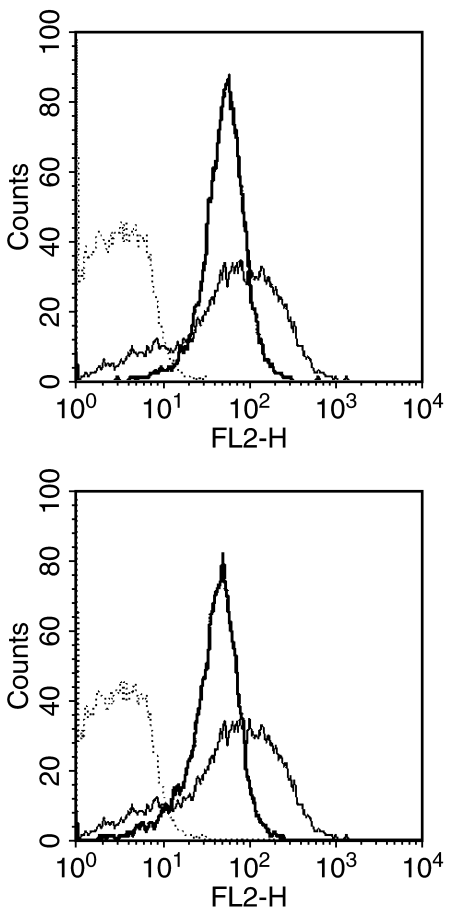

- $\mathrm{CD}^{-}$parental cell line

- $\mathrm{CD}^{+}$cell line

- $\mathrm{CD}^{+}$targeted clone

Fig. 3. Stability of protein expression in targeted clones. (A) $\beta$-galactosidase expression was assayed by the ONPG test for 4 independent targeted clones $(\diamond)$ and for the parental cell line ( $\mathbf{\square}$ ) over a period of $16 \mathrm{wk}$. The mean and standard deviation of expression levels for these 4 clones is plotted against time. (B) CD4-expression of a targeted clone was measured by FACS over a period of $16 \mathrm{wk}$. FACS displays for week 2 and 16 are shown. The CD4 expression of the targeted clone (bold line) is compared with the CD4-, parental cells (light line) and to endogenous CD4 expressing cells (dotted line).

\section{Notes}

1. For optimal transfection efficiency, the cells should not be more than $80 \%$ confluent. For the same reason, we recommend to use cells with low passage number.

2. For optimal transfection efficiency, the plasmid DNA must be produced with an endotoxin-free preparation technique.

3. The cells should not stay more than $20 \mathrm{~min}$ in solution $\mathrm{T}$.

4. gDNA pellet is quite difficult to resuspend in TE, unless if not dried completely.

5. The resuspension time may vary from sample to sample. It can take several hours. Do not hesitate to gently mix the DNA from time to time. 
6. Trays, combs, and electrophoresis apparatus is carefully cleaned with soap and rinsed with distilled water. This step is crucial because dirty materials can impair the final result.

7. At this step, the membrane can be stored between two pieces of Whatmann paper for a long period of time.

8. The same probe can be used three to four times. When using a new aliquot, we recommend performing a first hybridization with a useless membrane. We noticed that the background is diminished when a probe has been used one or two times.

9. When performing the anti-DIG antibody revelation, it is important not to let the membrane dry up during the steps. Otherwise, a very high background will occur.

10. Hybridized membranes can be stored at $-20^{\circ} \mathrm{C}$ in their plastic bag. Alternatively, they can be stripped by a short incubation in denaturation buffer $(10 \mathrm{~min})$ followed by two quick bath in distilled water first and then in $200 \mathrm{mM} \mathrm{Na} \mathrm{HPO}_{4}, \mathrm{pH}$ 7.2. The membrane is dried on Whatmann paper and stored at room temperature. This membrane can be reprobed but usually the reprobing does not give satisfactory results.

11. Because the CD4 protein is expressed at the cell surface, the Versene solution is used to collect the cells. This solution is preferred to the trypsin-EDTA solution because the trypsin can degrade surface molecules. As the Versene solution is less efficient than the trypsin-EDTA solution, it is recommended to gently scrap the cells after the $5 \mathrm{~min}$ incubation before the addition of medium. Furthermore, multiple samples are treated one at a time.

\section{Acknowledgment}

We thank Luc Mathis for critical reading of the manuscript.

\section{References}

1. Hinnen, A., Hicks, J. B., and Fink, G. R. (1978) Transformation of yeast. Proc. Natl. Acad. Sci. USA 75, 1929-1933.

2. Rothstein, R. J. (1983) One-step gene disruption in yeast. Methods Enzymol. 101, 202-211.

3. Thomas, K. R. and Capecchi, M. R. (1987) Site-directed mutagenesis by gene targeting in mouse embryo-derived stem cells. Cell 51, 503-512.

4. Capecchi, M. R. (2001) Generating mice with targeted mutations. Nat. Med. 7, 1086-1090.

5. Smithies, O. (2001) Forty years with homologous recombination. Nat. Med. 7, 1083-1086.

6. Rouet, P., Smih, F., and Jasin, M. (1994) Introduction of double-strand breaks into the genome of mouse cells by expression of a rare-cutting endonuclease. Mol. Cell Biol. 14, 8096-8106.

7. Choulika, A., Perrin, A., Dujon, B., and Nicolas, J. F. (1995) Induction of homologous recombination in mammalian chromosomes by using the I-SceI system of Saccharomyces cerevisiae. Mol. Cell Biol. 15, 1968-1973.

8. Chevalier, B. S. and Stoddard, B. L. (2001) Homing endonucleases: structural and functional insight into the catalysts of intron/intein mobility. Nucleic Acids Res. 29, 3757-3774. 
9. Dujon, B., Colleaux, L., Jacquier, A., Michel, F., and Monteilhet, C. (1986) Mitochondrial introns as mobile genetic elements: the role of intron-encoded proteins. Basic Life Sci. 40, 5-27.

10. Haber, J. E. (1995) In vivo biochemistry: physical monitoring of recombination induced by site-specific endonucleases. Bioessays 17, 609-620.

11. Posfai, G., Kolisnychenko, V., Bereczki, Z., and Blattner, F. R. (1999) Markerless gene replacement in Escherichia coli stimulated by a double-strand break in the chromosome. Nucleic Acids Res. 27, 4409-4415.

12. Sargent, R. G., Brenneman, M. A., and Wilson, J. H. (1997) Repair of site-specific double-strand breaks in a mammalian chromosome by homologous and illegitimate recombination. Mol. Cell Biol. 17, 267-277.

13. Donoho, G., Jasin, M., and Berg, P. (1998) Analysis of gene targeting and intrachromosomal homologous recombination stimulated by genomic double-strand breaks in mouse embryonic stem cells. Mol. Cell Biol. 18, 4070-4078.

14. Cohen-Tannoudji, M., Robine, S., Choulika, A., et al. (1998) I-SceI-induced gene replacement at a natural locus in embryonic stem cells. Mol. Cell Biol. 18, 1444-1448.

15. Gouble, A., Smith, J., Bruneau, S., et al. (2006) Efficient in toto targeted recombination in mouse liver by meganuclease-induced double-strand break. J. Gene Med. 8, 616-622.

16. Siebert, R. and Puchta, H. (2002) Efficient repair of genomic double-strand breaks by homologous recombination between directly repeated sequences in the plant genome. Plant Cell 14, 1121-1131.

17. Puchta, H., Dujon, B., and Hohn, B. (1996) Two different but related mechanisms are used in plants for the repair of genomic double-strand breaks by homologous recombination. Proc. Natl. Acad. Sci. USA 93, 5055-5060.

18. Arnould, S., Chames, P., Perez, C., et al. (2006) Engineering of large numbers of highly specific homing endonucleases that induce recombination on novel DNA targets. J. Mol. Biol. 355, 443-458.

19. Smith, J., Grizot, S., Arnould, S., et al. (2006) A combinatorial approach to create artificial homing endonucleases cleaving chosen sequences. Nucleic Acids Res. 34, E149.

20. Smith, J., Bibikova, M., Whitby, F. G., Reddy, A. R., Chandrasegaran, S., and Carroll, D. (2000) Requirements for double-strand cleavage by chimeric restriction enzymes with zinc finger DNA-recognition domains. Nucleic Acids Res. 28, 3361-3369.

21. Urnov, F. D., Miller, J. C., Lee, Y. L., et al. (2005) Highly efficient endogenous human gene correction using designed zinc-finger nucleases. Nature 435, 646-651.

22. Wurm, F. M. (2004) Production of recombinant protein therapeutics in cultivated mammalian cells. Nat. Biotechnol. 22, 1393-1398. 